\title{
CHANGES IN ANTIOXIDANT AND PHYSICOCHEMICAL PROPERTIES OF INDONESIAN BLACK RICE FLOUR (VAR. BANJARNEGARA AND BANTUL) DURING NO-DIE EXTRUSION COOKING
}

\section{[Perubahan Sifat Antioksidan dan Fisikokimia Tepung Beras Hitam Asal Indonesia (var. Banjarnegara dan Bantul) akibat Proses Pemasakan Ekstrusi tanpa Cetakan]}

\author{
Diana Ayu Nindita ${ }^{1)}$, Feri Kusnandar ${ }^{1,2) \star}$ and Slamet Budijanto ${ }^{1,2)}$ \\ ${ }^{1)}$ Department of Food Science and Technology, Faculty of Agricultural Engineering and Technology, Bogor Agricultural University, Bogor \\ 2) South East Asia Food and Agricultural Science and Technology (SEAFAST) Center, Bogor Agricultural University, Bogor
}

\author{
Received $26^{\text {th }}$ December $2017 /$ Accepted $16^{\text {th }}$ October 2018
}

\begin{abstract}
This research aimed to evaluate the effect of extrusion cooking conditions (barrel temperature and feed moisture content) on the changes in the physicochemical properties and antioxidant activity of the Indonesian black rice flour (var. Banjarnegara and Bantul). The rice flours were extruded using a no-die twin screw extruder at various barrel temperatures $\left(110\right.$ and $\left.140^{\circ} \mathrm{C}\right)$ and moisture content of $15,20,25 \%$ (wb). The total phenolic content (TPC), total anthocyanin content (TAC), and antioxidant activity generally decreased by 29,46 , and $19 \%$, respectively. During extrusion cooking, the higher moisture content resulted in a higher retention of anthocyanins hence increased the antioxidant activity as measured by DPPH assay. Increasing temperature produced less retention of both anthocyanins and phenolics, hence lowering the antioxidant activity. The water absomtion of the products also increased as the moisture content and barrel temperature increased, while the water solubility of the products became lower as the moisture content increased. Following a no-die extrusion cooking, both varieties of the black rice experienced changes with regard to the physicochemical properties and antioxidant activity. Due to the high antioxidant activity (DPPH value of $510.4 \mathrm{mg}$ Trolox equiv/100 g) and FRAP value of $2340.9 \mathrm{mg}$ Trolox equiv/100 g), the black rice var. Banjarnegara is recommended for further development. No-die extrusion cooking conditions at $110^{\circ} \mathrm{C}$ and moisture content of more than $25 \%$ is selected to achieve fully gelatinized flour with high antioxidant activity.
\end{abstract}

Keywords: anthocyanin, antioxidant properties, black rice, extrusion cooking, physicochemical properties

\section{ABSTRAK}

Penelitian ini bertujuan untuk mengevaluasi pengaruh pemasakan ekstrusi (suhu barel dan kadar air masukan) terhadap perubahan sifat fisikokimia dan aktivitas antioksidan dari tepung beras hitam asal Indonesia (var. Banjarnegara and Bantul). Tepung beras diekstrusi dengan ekstruder ulir ganda tanpa cetakan pada variasi suhu barel $\left(110\right.$ dan $\left.140^{\circ} \mathrm{C}\right)$ dan kadar air (15, 20, 25\%, basis basah). Secara umum, kandungan total fenol, total antosianin, dan aktivitas antioksidan menurun oleh pemasakan ekstrusi. Kadar air yang lebih tinggi meningkatkan retensi kerusakan antosianin, yang terlihat dari peningkatan aktivitas antioksidan yang diukur dengan DPPH assay. Peningkatan suhu barel menurunkan retensi antosianin dan fenol, sehingga menurunkan aktivitas antioksidannya. Penyerapan air pada produk juga meningkat seiring dengan kenaikan kadar air dan suhu barel, sementara kelarutan air pada produk menurun seiring dengan semakin rendahnya kadar air yang digunakan. Pada pemasakan ekstrusi, kedua varietas beras hitam Bantul and Banjarnegara mengalami perubahan sifat fisikokimia dan aktivitas antioksidan. Penggunaan beras hitam Banjarnegara yang memiliki kadar antioksidan yang lebih tinggi dibandingkan beras hitam Bantul direkomendasikan untuk dipilih. Kondisi yang sesuai adalah pemasakan ekstrusi tanpa cetakan diatur pada suhu $110^{\circ} \mathrm{C}$ dan kadar air masukan lebih dari $25 \%$ untuk mencapai tepung yang tergelatinisasi secara sempurna dengan aktivitas antiosidan yang tinggi.

Kata kunci: antosianin, beras hitam, pemasakan ekstrusi, sifat antioksidan, sifat fisikokimia

\section{INTRODUCTION}

Rice (Oryza sativa L.) is one of the staple foods for more than 3 billion people in more than 100

\footnotetext{
*Corresponding Author:

E-mail: fkusnandar@gmail.com
}

countries of the world (Birla et al., 2017). Based on the bran color, rice is classified into non-pigmented rice and pigmented rice (Goufo and Trindade, 2014). Pigmented rice cultivars are reported as potent sources of antioxidants and are encouraged as a functional food (Reddy et al., 2016). Raw black rice has the highest antioxidant activity as it is the richest source 
of phenolic acids, flavonoids and anthocyanins compared to brown, red, and purple rice (Goufo and Trindade, 2014). Previous studies have shown that anthocyanins in black rice possessed anti-cancer properties as well as anti-inflammatory and antiatherogenic properties to prevent cardiovascular diseases (Min et al., 2010; Hui et al., 2010). Thus, black rice is one of the promising functional foods to meet the demands of health conscious consumers.

Pratiwi and Purwesti (2017) revealed that there were 24 varieties of Indonesian black rice; six varieties from Central Java, five varieties from Yogyakarta, four varieties from Nusa Tenggara Timur (NTT), six varieties from Sulawesi, and one variety each from Kalimantan and West Java. The black rice varieties were named after their origin area, for instance the Bantul black rice from Bantul area in Yogyakarta province (Kristamtini et al., 2014). However, there were very rare data on Indonesian black rice production except the production of Waja Loka and Laka black rice variety from NTT cultivated in irrigated organic paddy field that only reached 6 tons/ha and 8 tons/ha in dry season, respectively (Budiman et al., 2012). Black rice is still rarely consumed in Indonesia, but it has been sold as unmilled rice. The number of research on Indonesian black rice is still growing, and the researches considering antioxidants in Indonesian black rice are also still limited to the antioxidant activity in raw flour, cooked rice, and beverages from its cooking water (Hartati, 2013; Handayani et al., 2014).

The growing demand of black rice creates the opportunity for the new product development, such as instant porridge, rice noodle, and rice snacks. These processed foods production utilize extrusion cooking, which is a rapid processing method involving high temperature and pressure in a short time. Extrusion cooking is able to change the amount and profiles of food nutritional and functional components, which may be either beneficial or deleterious. These changes are mostly caused by extrusion cooking conditions, such as barrel temperature, feed moisture, screw speed, and flow rate (Brennan et al., 2011). Sompong et al. (2011) reported that feed moisture only affected the retention of total phenolic and did not affect the retention of anthocyanin and antioxidant activities in the extrusion cooking of Thailand black rice. There has been no report on the extrusion cooking of Indonesian black rice, especially the effect of its process conditions.

The objective of this research was therefore to investigate the influence of extrusion cooking conditions to obtain pre-gelatinised flours for ingredient purposes, especially barrel temperature and feed moisture content, on the retention of total phenolics, anthocyanins, and antioxidant activity of the black rice flour. Moreover, the changes on the physicoche- mical properties, such as water solubility, water absorption, and color, were also evaluated.

\section{MATERIALS AND METHODS}

\section{Materials}

Black rice (Oryza sativa L. indica) cultivar Banjarnegara and Bantul black rice were purchased from farmer association in Cigudeg, West Java, Indonesia. According to our sample characterization, the amylose content of Banjarnegara black rice is $1.31 \%$ and Bantul black rice is $2.04 \%$. Based on the classification by Sompong et al. (2011), Banjarnegara black rice was classified as waxy $(<2 \%)$ and Bantul black rice as very low amylose (2-9\%).

\section{Sample preparation}

Preparation of rice flour for extrusion cooking experiments was done by husking the black rice grains twice using rice huller (Yanmar rice huller model W-60A, Japan) and milling them by passing through 80-mesh sieve in a stainless steel disk mill (Agrowindo stainless steel disk mill model AGC 21, Indonesia). The flours obtained were stored at divided into $1 \mathrm{~kg}$ portions for each application, packaged in vacuum aluminum foil bags and stored at $18^{\circ} \mathrm{C}$ prior to use.

\section{Extrusion cooking}

Rice flour samples were extruded in duplicate using a no-die twin-screw extruder (Berto BEX-DS2256, Indonesia) with a screw length of $900 \mathrm{~mm}$ and diameter of $64.5-50 \mathrm{~mm}$. Feed rate for all experimental results was set at $19.7 \mathrm{~kg} / \mathrm{h}$. No die applied for the extrusion cooking, so that no expansion of the extrudates occurred as the aim of this study was not to achieve well expanded extrudates but pregelatinised flours for ingredient purposes.

The screw speed was maintained at $80 \mathrm{rpm}$. The temperature profile in the first two barrel sections from the feed was maintained at 50 and $70^{\circ} \mathrm{C}$, while the third barrel section was set at 110 or $140^{\circ} \mathrm{C}$ as the variable of processing. The moisture content of each black rice flours was determined prior to extrusion cooking (AOAC, 2012) and later adjusted by adding water to reach three different levels of moisture content $(15,20$, and $25 \%$; wet basis). The addition of water was conducted by spraying then the flours were stored at $-18^{\circ} \mathrm{C}$ in a vacuum foil bag to reach equilibrium for $24 \mathrm{~h}$ before extrusion. Pre-gelatinised flours obtained from extrusion were packed into $1 \mathrm{~kg}$ portion each and stored at $-18^{\circ} \mathrm{C}$ in airtight aluminum foil bags for further analysis.

\section{Extraction of phenolic compounds}

Phenolic compounds of unprocessed and extruded rice flour samples were extracted using the 
method by Zhang et al. (2010). Briefly, $5 \mathrm{~g}$ of black rice flour was blended with $50 \mathrm{~mL}$ of chilled acidified Methanol using 95\% Methanol (Merck, Germa-ny) and $1 \mathrm{M} \mathrm{HCl}$ (Merck, Germany) in ratio of $85: 15$ $(\mathrm{v} / \mathrm{v})$. The mixture then was centrifuged (IEC Centra8 Centrifuge, Waltham, MA) at $2500 \times \mathrm{g}$ for $10 \mathrm{~min}$. The supernatant was removed, and the remaining pellet was again extracted with $50 \mathrm{~mL}$ of chilled acidified Methanol. The supernatant was pooled and made up to a final volume of $100 \mathrm{~mL}$ with chilled acidified methanol. The extracts were stored at $18^{\circ} \mathrm{C}$ in dark bottles until analysis.

\section{Determination of total phenolic content}

The total phenolic content (TPC) of unprocessed and extruded rice flour extract was determined by Folin-Ciocalteu spectrometric method ( $T i$ et al., 2015) with a slight modification. The phenolic extracts of Banjarnegara and Bantul black rice flour were first diluted 100 -fold and 50-fold respectively in acidified Methanol (95\% Methanol and $1 \mathrm{M} \mathrm{HCl}$ $85: 15, v / v)$. An aliquot of extract $(600 \mu \mathrm{L})$ was reacted with $3.0 \mathrm{~mL}$ freshly diluted (10-fold) Folin-Ciocalteu reagent (Merck, Germany). The mixture was allowed to equilibrate for $10 \mathrm{~min}$ and then neutrallized with $2.4 \mathrm{~mL}$ of sodium carbonate (Sigma Aldrich, USA) solution $(75 \mathrm{~g} / \mathrm{L})$. After incubation at a room temperature $\left(25^{\circ} \mathrm{C}\right)$ for $90 \mathrm{~min}$, the absorbance of the resulting solution was measured at $747 \mathrm{~nm}$ using UV-Vis spectrometer (Shimadzu, UV-1800, Japan). Samples were assayed in duplicate and Gallic acid (Sigma Aldrich, USA) was used as the standard. TPC was expressed as $\mathrm{mg}$ of $\mathrm{Gallic}$ acid equivalents (GAE) per $100 \mathrm{~g}$ of dry weight of sample.

\section{Determination of total anthocyanin content}

Determination of total anthocyanin content (TAC) was conducted using a spectrophotometric pH differential method by Lee et al. (2016). The phenolic extracts of Banjarnegara and Bantul black rice flour were first diluted 100 -fold and 50 -fold respectively in acidified Methanol (95\% methanol and $1 \mathrm{M}$ $\mathrm{HCl} 85: 15, \mathrm{v} / \mathrm{v})$. The extracts were mixed thoroughly with $0.025 \mathrm{M}$ Potassium chloride (Merck, Germany) buffer $(\mathrm{pH} 1)$. The absorbance of the mixture was then measured using UV-Vis spectrometer (Shimadzu, UV-1800, Japan) at 515 and $700 \mathrm{~nm}$ against distilled water blank. Similarly, the above extracts were dissolved with Sodium acetate (Merck, Germany) buffer ( $\mathrm{pH} 4.5)$ and the absorbance of these solutions was measured at the same wavelengths. The anthocyanin content was calculated by:

Total anthocyanins $(\mathrm{mg} / 100 \mathrm{~g}$ dry sample $)=\frac{\mathrm{A} \times \mathrm{MW} \times \mathrm{DF} \times 1000}{(\varepsilon \times \mathrm{C})}$

where, $\varepsilon$ is the molar absorptivity of Cyanidin-3glucoside $(\mathrm{Cy}-3-\mathrm{G})=26.900 ; \mathrm{C}$ is the concentration of the buffer in $\mathrm{mg} / \mathrm{mL}$; $A$ is absorbance $=\left(A_{515}-\right.$ $\left.A_{700}\right)_{\mathrm{pH}} 1.0-\left(A_{515}-A_{700}\right)_{\mathrm{pH}} 4.5 ; \mathrm{MW}$ is the molecular weight of Cy-3- $G=449.2$; and DF is the dilution factor. The anthocyanin content was expressed as the mean of $\mathrm{mg}$ Cy-3-G equivalents per $100 \mathrm{~g}$ dry sample \pm SD for duplicate samples.

\section{Determination of DPPH free radical scavenging activity}

Analysis of 2,2-Diphenyl-1-picrylhydrazyl (DPP $\mathrm{H})$ free radical scavenging capacity was performed using 96-well plate assay method from Bobo-garcía et al. (2014). The phenolic extracts of Banjarnegara and Bantul black rice flour were first diluted 100 -fold and 50 -fold respectively in acidified Methanol (95\% methanol and $1 \mathrm{M} \mathrm{HCl} 85: 15, \mathrm{v} / \mathrm{v})$. A total of $20 \mu \mathrm{L}$ of diluted sample was reacted with $180 \mu \mathrm{L}$ of $\mathrm{DPPH}$ (Sigma Aldrich, USA) solution (150 $\left.\mu \mathrm{mol} \mathrm{L}^{-1}\right)$ in methanol-water $(80: 20, \mathrm{v} / \mathrm{v})$ and shaken for $60 \mathrm{~s}$ in a 96-well microplate (Iwaki, Japan). The absorbance was measured at $515 \mathrm{~nm}$ in the ELISA microplate reader (Biotek Instruments, Winooski, USA) after 40 min incubation in the dark at room temperature. Trolox (Sigma Aldrich, USA) was used as a standard at $100-500 \mu \mathrm{mol} \mathrm{L}^{-1}$ and the $\%$ DPPH quenched was calculated by:

$$
\% \text { DPPH quenched }=\left[1-\left(\frac{A_{\text {sample }}-A_{\text {blank }}}{A_{\text {control }}-A_{\text {blank }}}\right) \times 100\right]
$$

where, $A_{\text {sample }}$ is the absorbance at $515 \mathrm{~nm}$ of $20 \mu \mathrm{l}$ of extract or standard with $180 \mu \mathrm{L}$ DPPH solution after $40 \mathrm{~min}$; $A_{\text {blank }}$ is the absorbance at $515 \mathrm{~nm}$ of $20 \mu \mathrm{L}$ of water with $180 \mu \mathrm{l}$ Methanol-water (80:20, $\mathrm{v} / \mathrm{v}$ ) after $40 \mathrm{~min}, \mathrm{~A}_{\text {control }}$ is the absorbance at $515 \mathrm{~nm}$ of $20 \mu \mathrm{L}$ of water with $180 \mu \mathrm{L}$ DPPH solution after 40 min. The DPPH antioxidant activity was expressed as the mean of $\mathrm{mg}$ Trolox equivalent (TE) per $100 \mathrm{~g}$ dry sample for duplicate samples.

\section{FRAP analysis}

Determination of Ferric Reducing Ability Power (FRAP) of the free phenolic extracts from black rice flours and their extrudates was conducted following the method from Handayani et al. (2014). FRAP reagent was prepared by mixing $300 \mathrm{mM}$ acetate buffer (pH 3.6) containing $16 \mathrm{~mL}$ acetic acid (Merck, Germany) per litre of the buffer solution, $10 \mathrm{mM}$ 2,4,6,-Tripyridil-s-triazine (TPTZ) (Sigma Aldrich, USA) in $40 \mathrm{mM} \mathrm{HCl}$ and $20 \mathrm{mM} \mathrm{FeCl} 3.6 \mathrm{H}_{2} \mathrm{O}$ (Merck, Germany) in a ratio of $1: 1: 10$. The $2.7 \mathrm{~mL}$ freshly prepared FRAP reagent then were incubated to $37^{\circ} \mathrm{C}$. Then, the extract of sample $(150 \mu \mathrm{L})$ and 210 $\mu \mathrm{L}$ of distilled water were added to FRAP reagent then allowed to stand for $10 \mathrm{~min}$. The FRAP assay and acidified methanol as reagent blank absorbance were read at $593 \mathrm{~nm}$ using UV-Vis spectrometer (Shimadzu, UV-1800, Japan) and Trolox (Sigma 
Aldrich, USA) was used as standard. The measurements were done in duplicate and the results were expressed as $\mathrm{mg}$ Trolox equivalent (TE) per $100 \mathrm{~g}$ of dry sample.

\section{Water absorption index and water solubility index}

Water absorption index (WAI) and water solubility index (WSI) of samples were determined by a modified method from Sompong et al. (2011). Each flour $(2.5 \mathrm{~g})$ was dispersed in $30 \mathrm{~mL}$ of distilled water at room temperature for 30 min with a gentle stirring every $5 \mathrm{~min}$. Then the samples were centri-fuged (IEC Centra-8 Centrifuge, Waltham, MA) at $1500 \times 9$ for $20 \mathrm{~min}$. The supernatant was decanted into a tared aluminum pan and dried at $105^{\circ} \mathrm{C}$ until constant weight. The weights of the gel remaining in the centrifuge tubes were noted. The measurements were done in duplicate. WAI were calculated as weight gain of gel/dry weight of sample and WSI were calculated as weight of dry solid in supernatant $\times 100 /$ dry weight of samples.

\section{Experimental design and statistical analysis}

The experimental design was carried out for three independent variables, rice variety (Banjarnegara and Bantul black rice), temperature $\left(\mathrm{T}, 110^{\circ} \mathrm{C}\right.$ and $140^{\circ} \mathrm{C}$ ), and moisture content $(15 ; 20$; and $25 \%$ in wet basis) by applying a $2 \times 2 \times 3$ factorial design . All statistical analyses of data were carried out using SPSS version 22.0 statistical software for analysis of variance. Significant differences between means were determined by the univariate analysis. Significant differences between means were determined by Duncan's Multiple Range Tests. Correlation coefficients amongst data obtained were calculated using Pearson's correlation coefficients $(r)$.

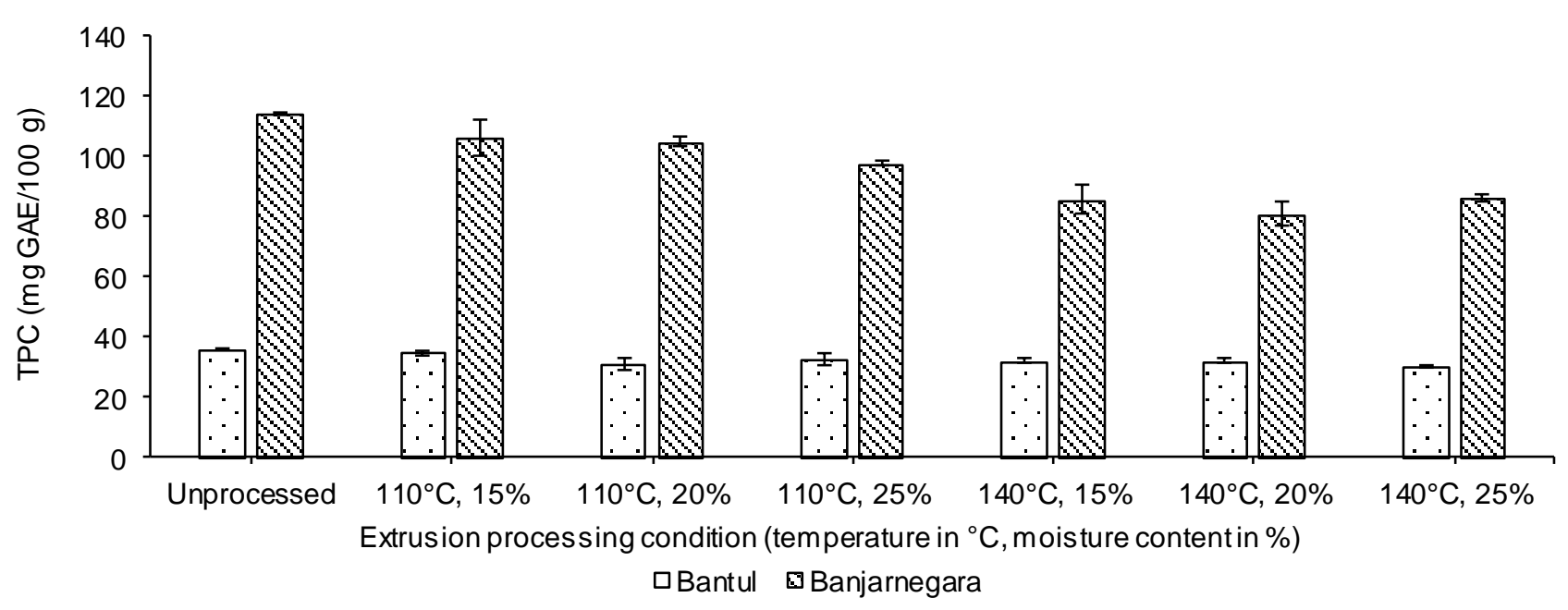

Figure 1. Total phenolic content (TPC) of Banjarnegara and Bantul black rice flours as the effect of rice

variety, barrel temperature, and moisture content

\section{RESULTS AND DISCUSSION}

\section{Total phenolic content}

The total phenolic content (TPC) from the phenolic extracts of unprocessed and extruded Bantul and Banjarnegara black rice flour were exhibited in Figure 1. The TPC values of waxy Banjarnegara black rice flour was significantly higher $(P<0.001)$ than low amylose Bantul rice, which was in opposite to the findings by Tang et al. (2015) who reported that non-waxy black rice had higher TPC than waxy black rice. In addition, the TPC values of unprocessed Bantul black rice and Banjarnegara rice (36.01 $\mathrm{mg} \mathrm{GAE} / 100 \mathrm{~g}$ and $114.06 \mathrm{mg} \mathrm{GAE} / 100 \mathrm{~g}$, respectively) were lower than that of black rice from Thailand whose TPC was $351.23 \mathrm{mg} / 100 \mathrm{~g}$ (Sompong et al. 2011) and from China (Oryza sativa var. Heiyounian) whose TPC was $545.8 \mathrm{mg} \mathrm{GAE} / 100 \mathrm{~g}$ (Ti et al., 2015). Possibly, black rice growing under different environments and regions produce different physical characteristics and chemical compositions. Apart from this reason, the method of extraction plays an important role to the various obtained TPC values.

In this studies, the TPC of Banjarnegara black rice flour decreased significantly $(P<0.05)$ to its corresponding control (unprocessed flour) sample. This result is consistent with previous black rice extrusion studies carried out by Sompong et al. (2011) and Ti et al. (2015). However, in this study, the highest reduction of TPC was $29.3 \%$, which was not as high as reported in the two previous studies (59.8-79.5\% of reduction). Rice variety, barrel temperature, and their interaction affected TPC significantly $(P<0.001)$. Although no-die extrusion cooking generally exhibited a negative effect on TPC, the degree of the influence between Banjarnegara rice and Bantul black rice was different. 
The difference between rice varieties most likely was caused by the difference in amylose content. Extrusion gave more declines of TPC values to waxy Banjarnegara rice flour than low amylose Bantul rice flour. In Bantul rice flour, within all the moisture content and barrel temperature given, there were no significant differences in their TPC values. These results were in opposite with the findings reported by Tang et al. (2015), in which waxy black rice had no significant change in TPC values upon two different cooking method (i.e. cooked rice and porridge) while non-waxy black rice showed significant $(P<0.05)$ changes in TPC values after the two cooking treatments.

Increasing barrel temperature from $110^{\circ} \mathrm{C}$ to $140^{\circ} \mathrm{C}$ within the same moisture content resulted in significant $(P<0.001)$ reduction of TPC in Banjarnegara black rice by $12.2-22.9 \%$. These results are consistent with those reported by Sharma et al. (2012) when the temperature was increased from 150 to $180^{\circ} \mathrm{C}$ for the extrusion of barley cultivars. The reduction of TPC owing to decarboxylation of phenolic compounds in high extrusion temperature, leading to the reduction in their chemical reactivity or their extractability due to certain degree of polymerization (Altan et al. 2009).

Increased moisture content alone affected the TPC insignificantly $(P>0.05)$. These results were in contrast to the black rice extrusion studies by Sompong et al. (2011) when increasing moisture content from 12 to $16 \%$ and with Sarawong et al., (2014) who reported $17.5-42.8 \%$ reduction of TPC for extruded green banana flour when increasing moisture content (from 20 to 50\%). However, there was a significant effect $(P<0.05)$ of combined interaction between moisture content, rice variety, and barrel temperature. Within this interaction, high feed moisture content may promote polymerization of phenols, leading to reduced extractability and antioxidant activity. As the combined interaction between moisture content, rice varieties, and barrel temperature affected the TPC values, there might be optimum TPC result achieved from one condition applied from the three variables. Therefore, due to no-die extrusion cooking, the optimum TPC result (106.13 mg GAE/100 g) was obtained by extruding Banjarnegara black rice with barrel temperature $110^{\circ} \mathrm{C}$ and $15 \%(\mathrm{wb})$ of moisture content as the extrusion cooking condition.

\section{Total anthocyanin content}

The total anthocyanin content (TAC) from the phenolic extracts of Banjarnegara and Bantul unprocessed and extruded black rice flour were exhibited in Figure 2. TAC of unprocessed Banjarnegara black rice was $179.30 \mathrm{mg}$ Cy-3-G equiv/100 g and unprocessed Bantul black rice was $70.30 \mathrm{mg}$ Cy-3-G equiv/100 g. Meanwhile, Kristamtini et al. (2014) reported that the TAC value of Banjarnegara black rice was $165.78 \mathrm{mg}$ Cy-3-G equiv/100 g and unprocessed Bantul black rice was 90.22 Cy-3-G equiv/ $100 \mathrm{~g}$. The differences in anthocyanin content among black rices were might be because of differences in growing conditions and extraction method among the studies (Tang et al., 2015). Banjarnegara had significantly $(P<0.001)$ higher TAC value than Bantul, in agreement with TAC based Indonesian black rice cultivars classification made by Kristamtini et al. (2014), which classify Banjarnegara black rice in cultivar group II and Bantul black rice in cultivar group III. Numerous studies have suggested that Cyanidin-3-glucoside (Cy-3-G) is the most dominant anthocyanin in black rice, and the minor one is Peonidin-3-glucoside (Pe-3-G), in which each rice varieties had different composition of anthocyanin compounds (Tang et al., 2015; Goufo and Trindade, 2014).

In general, no-die extrusion cooking caused significant decrease in TAC values of both rice flour extrudates, with reduction range from 8.6 to $46.2 \%$ for extruded Banjarnegara black rice flour and 7.1 to $46.5 \%$ for extruded Bantul rice flour. These results were consistent with the studies by Sompong et al. (2011) and $\mathrm{Ti}$ et al. (2015). All condition variable (moisture content, barrel temperature, and rice varieties) and their interactions affected the TAC values significantly $(P<0.001)$. Although no-die extrusion cooking generally exhibited a negative effect on TAC, the degree of the influence between Banjarnegara and Bantul black rice was different. Extrusion gave more declines of TAC values to low amylose Bantul rice flour than waxy Banjarnegara rice flour. The difference between rice varieties most likely was because of the difference in their anthocyanins composition, in which each of anthocyanins had different degradation rate (Tang et al., 2015).

Increasing barrel temperature caused significant $(P<0.001)$ less retention of anthocyanins by $1.8-29.8 \%$ in Banjarnegara black rice and up to $17.2 \%$ in Bantul rice. The losses of anthocyanins may be attributed to the degradation of Cyanidin-3glucoside into protocatechuic acid, arising from thermal processing (Hiemori et al., 2009). Patras et al. (2010) also reported that thermal degradation of Cyanidin-3-Glucoside might obtained Phloroglucinaldehyde and 4-hydroxy-benzoic acid through deglycosylation and cleavage mechanism.

Within the constant barrel temperature, increased moisture content caused increase anthocyanin retention significantly $(P<0.001)$ up to $4.9 \%$ in Bantul rice flour extrudates and up to $38.4 \%$ in Banjarnegara rice flour extrudates. Higher moisture content has protective effect on bioactive compounds as high moisture content increases shear stress, resulting in less dissipating heating (Hirth et al., 2014). 


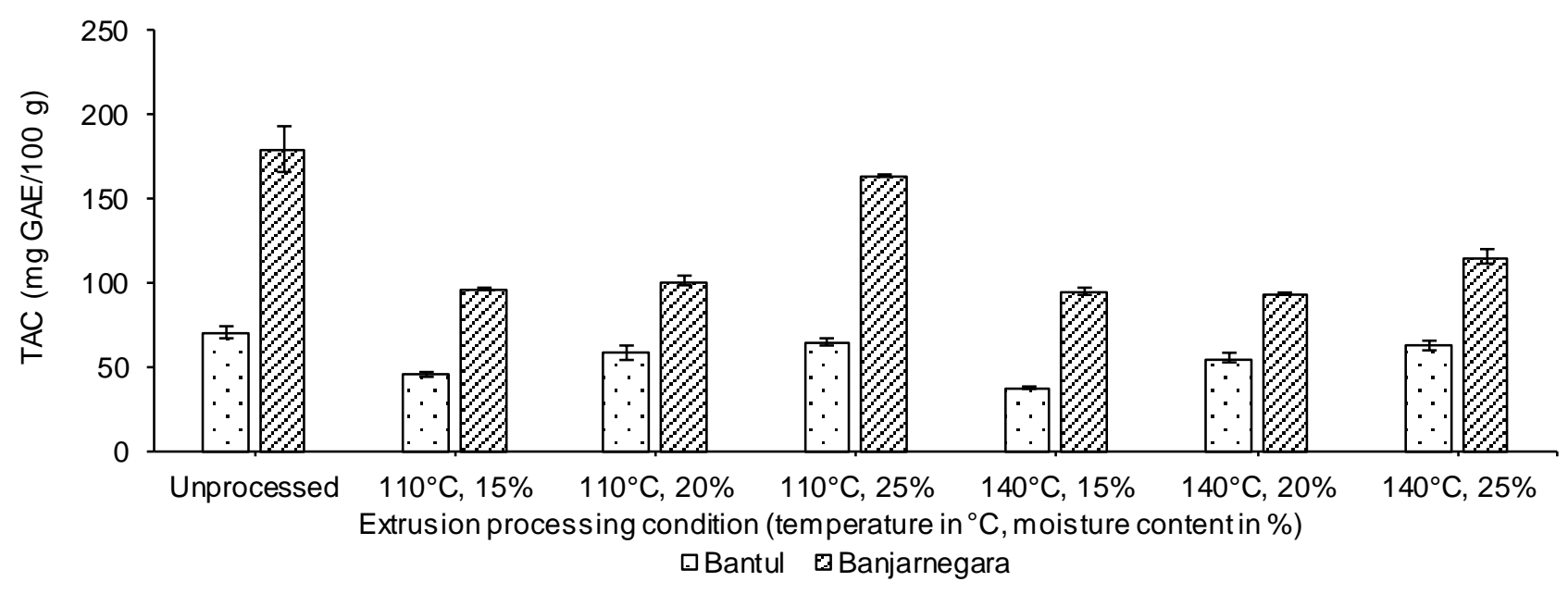

Figure 2. Total anthocyanin content (TAC) of Banjarnegara and Bantul black rice flours as the effect of rice variety, barrel temperature, and moisture content

There was a significant effect $(P<0.001)$ of combined interaction between moisture content, rice varieties, and barrel temperature. As the consequence of the influence from combined interaction between moisture content, rice varieties, and barrel temperature, there also might be optimum TAC result achieved from one condition applied from the three variables. Therefore, due to no-die extrusion cooking, the optimum TAC result (163.86 mg Cy-3-G equiv/100 g) was obtained by extruding Banjarnegara black rice with barrel temperature $110^{\circ} \mathrm{C}$ and $25 \%$ (wb) of moisture content as the extrusion cooking condition.

\section{Antioxidant activity}

DPPH free radical scavenging capacities of the unprocessed and processed black rice were mentioned in Figure 3A. The DPPH value of unprocessed waxy Banjarnegara black rice (510.43 mg TE/100 g) was significantly higher $(P<0.001)$ than that of non-waxy Bantul black rice (251.96 mg TE/100 g). After no-die extrusion cooking, both two varieties (non-waxy and waxy) exhibited a decreasing tendency. However, different moisture content can trigger significant diversity of the DPPH values.

In general, DPPH values were reduced due to no-die extrusion cooking since there were mostly loss of phenolics and anthocyanins as antioxidant components that have been discussed above. Different rice variety caused significant difference $(P<$ 0.001 ) of DPPH values obtained. This means that Banjarnegara and Bantul black rice flour had different DPPH values in nature and also exhibited different antioxidant activity (measured by DPPH assay) changes behavior upon no-die extrusion cooking. This phenomenon can be explained by the difference of TPC and TAC values owned by both varieties.
Within constant barrel temperature, higher moisture content applied mostly resulted in increase of DPPH values $(P<0.05)$. These results may be caused by either the less retention of anthocyanins due to higher moisture content that was explained in the previous section, which was supported with the strong correlation between DPPH antioxidant activity and TAC $(r=0.805, P<0.001)$. Moreover, the DPPH antioxidant activity also affected by TPC owing to their strong correlation $(r=0.950, P<0.001)$, which was in opposite to the low correlation between DPPH and TPC in eight barley cultivars observed by Sharma et al. (2012). The increase in antioxidant activity also could be explained by the formation of antioxidative Maillard browning products which enhanced the antioxidant activity (Sharma et al., 2012). This is influenced by many factors, including reactant concentration, temperature, time, and water activity.

Barrel temperature alone caused insignificant reduction $(P>0.05)$ of DPPH values in the extrudates. These results were in opposite with the observation of eight barley cultivars which were extrusion cooked at $150 \mathrm{C}$ and $180^{\circ} \mathrm{C}$ (Sharma et al., 2012). But when temperature was combined with moisture content and either with moisture content and rice varieties, there were significant reduction $(P<0.05)$ of DPPH observed. The reduction of DPPH antioxidant activity due to higher barrel temperature might be correlated with the loss of anthocyanins and phenolics since there was a strong positive correlation between DPPH antioxidant activity and TAC $(r=0.805, P<0.01)$, as well as DPPH along with TPC $(r=0.950, P<0.001)$.

There was a significant effect $(P<0.05)$ of combined interaction between moisture content, rice varieties, and barrel temperature. As the consequence of the influence from combined interaction between moisture content, rice varieties, and barrel tempera- 
ture, it can be seen that there also might be optimum antioxidant activity measured by DPPH assay achieved from one condition applied from the three variables. Therefore, due to no-die extrusion cooking, the optimum DPPH value (537.57 mg TE/100 g) can be obtained by extruding Banjarnegara black rice with barrel temperature $110^{\circ} \mathrm{C}$ and $25 \%$ (wb) of moisture content as the extrusion cooking condition.

The FRAP values of unprocessed and extruded Banjarnegara and Bantul black rice were presented in Figure 3B. The FRAP values of unprocessed waxy Banjarnegara black rice and non-waxy Bantul black rice were measured individually and resulted in $537.56 \mathrm{mg} \mathrm{TE} / 100 \mathrm{~g}$ and $2340.96 \mathrm{mg} \mathrm{TE} / 100 \mathrm{~g}$, respectively. Hence, relatively stronger antioxidant activity profiles were shown in waxy Banjarnegara black rice rather than non-waxy Bantul black rice. $A$ similar result had been also gained from the determination of radical DPPH scavenging activity.

\section{Water absorptivity index and water solubility index}

Water absorptivity index (WAI) has been commonly referred to as the dispersion of starch excess water and is an indicator of the ability of flour to absorb water or for the swelling ability of starch. It depends on the availability of hydrophilic groups, which bind water molecules and on the gel forming capacity of macromolecules. WAI is increased by the degree of starch damage due to gelatinization and extrusion-induced fragmentation, i.e. molecular weight reduction of amylose and amylopectin. WSI is generally used as an index of degradation of molecular components, and thus is a measure for the degree of starch degradation during extrusion cooking (Mesquita et al., 2013). The WAI and WSI of unprocessed and extruded Banjarnegara and Bantul black rice flours. WAl of black rice flours and their extrudates were relatively low (range 1.43-2.05 g/g).
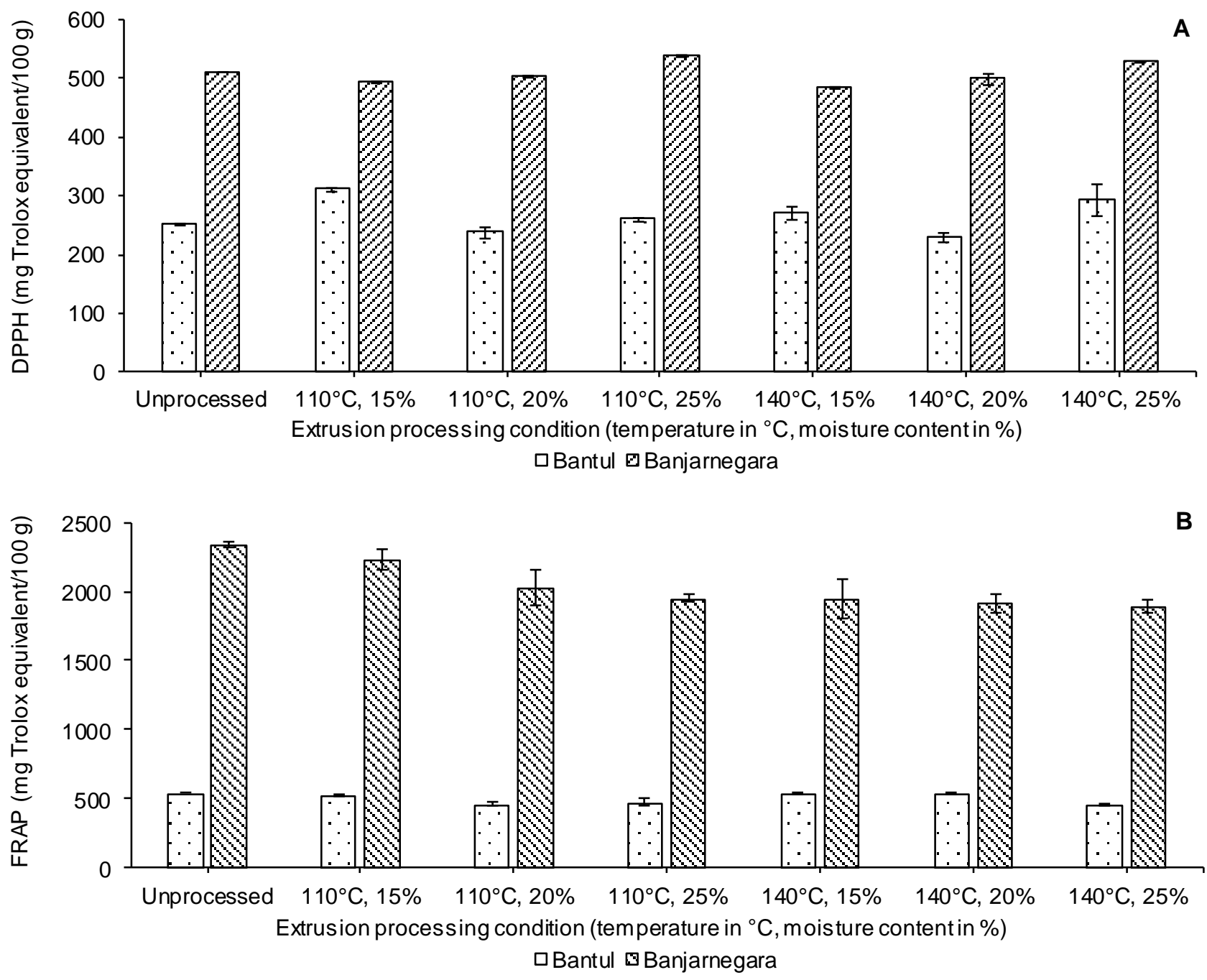

Figure 3. (A) DPPH antioxidant activity and (B) FRAP antioxidant activity of Banjarnegara and Bantul black rice flours as the effect of rice variety, barrel temperature, and moisture content 
WAI was significantly $(P<0.05)$ increased $(1.8$ $13.9 \%)$ by increasing barrel temperature for only Banjarnegara rice (Figure 4A), indicating that WAI was affected by rice variety and barrel temperature $(P<0.05)$. For Bantul rice, WAI was increased significantly $(P<0.05)$ after extruded at $140^{\circ} \mathrm{C}$ and the moisture content did not affect the WAI. These results were in agreement with the studies conducted by Sompong et al. (2011) and Sarawong et al. (2014). According to Sobukola et al. (2013), barrel temperature had significant effect to WAl, since at higher temperature, starch granule is disrupted and more water is bound to the starch molecule which resulting in increased WAI. In Banjarnegara black rice, eventhough not significant $(P>0.05)$, but there were increases of WAI when higher moisture was applied. At higher moisture content, viscosity of starch would be low, allowing the starch molecules to move freely and thereby enhancing the penetration of heat as a result greater gelatinisation. In addition, Sobukola et al. (2013) interpreted that higher moisture content imparts less shearing action in the barrel causing less mechanical damage to starch, thus increase WAl. However, there was no significant effect $(P>0.05)$ of the interaction between moisture content and barrel temperature to the WAI.

Water solubility index (WSI) is an indicator of the degradation of molecular components, in which represents the amount of soluble polysaccharide released from the starch after extrusion (Ding et al., 2005). WSI of black rice flours and their extrudates were relatively low (range 2.43-4.18\%) (Figure 15b). Since high amylose starch had high WSI values (Stojceska et al., 2009), it is easy to comprehend that low amylose and waxy black rice would have low WSI values. Due to no-die extrusion cooking, WSI value of Banjarnegara black rice was affected significantly $(P<0.001)$ by barrel temperature and moisture content. A higher moisture content caused significant $(P<0.001)$ decreased of WSI by $0.3-$ $28.2 \%$. Higher moisture content during extrusion resulting in a lower degree of starch gelatinization and probably acts as a plasticizer caused by reduced starch degradation, also due to less shearing taking place, thus resulting in a decrease in WSI (Seth et al., 2015).
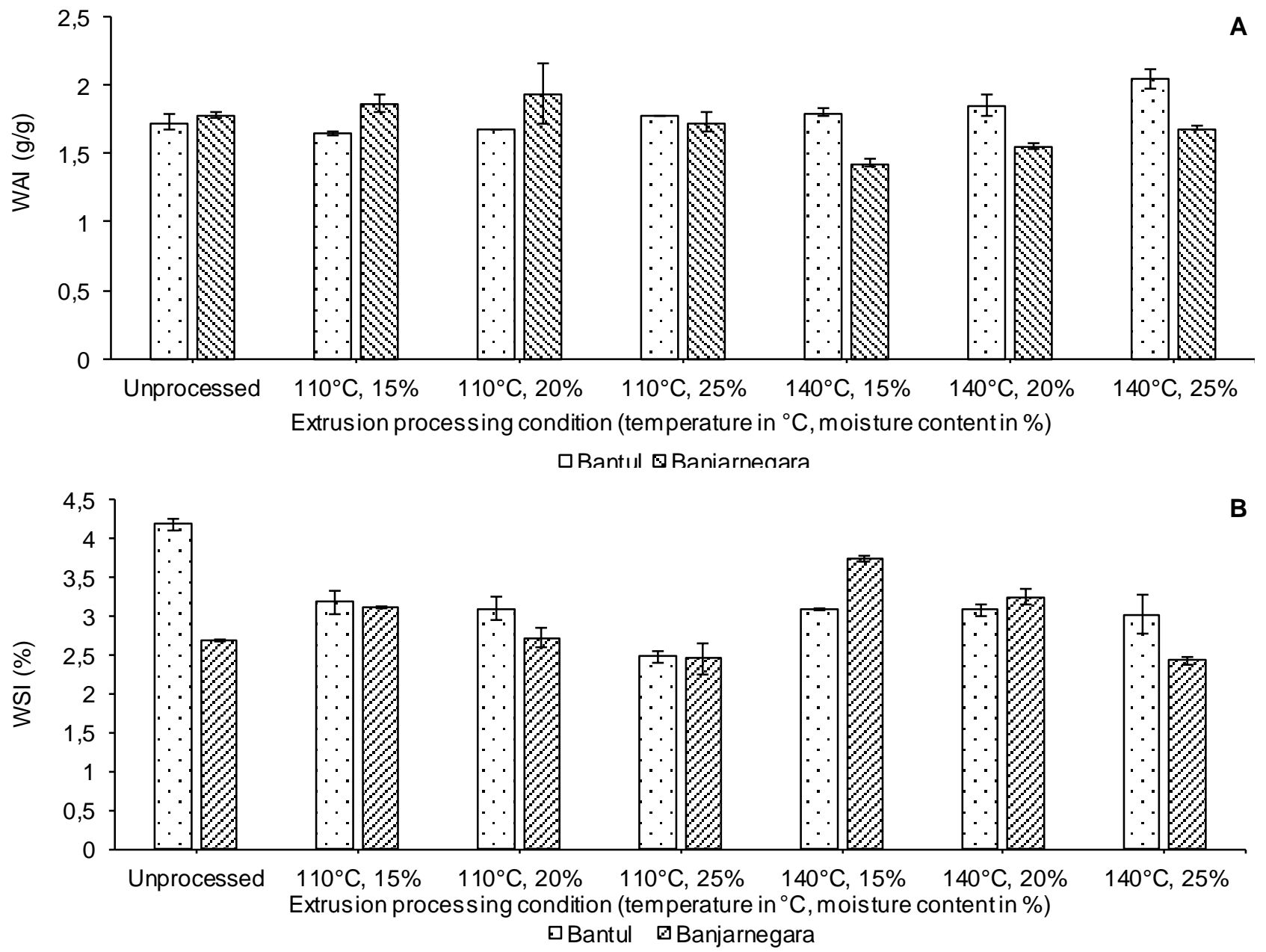

Figure 4. (A) Water absorptivity index (WAI) and (B) Water solubility index (WSI) of Banjarnegara and Bantul black rice flours as the effect of rice variety, barrel temperature, and moisture content 
Within constant moisture content, higher barrel temperature also increased WSI significantly $\left(P_{<}\right.$ 0.001 ) by up to $19.9 \%$. This could be due to starch degradation at higher temperature exposure to product inside the barrel and greater shearing action of the blend. Sobukola et al. (2013) reported that increased barrel temperature increases WSI, due to increased solubility of starch molecules. The WSI value is also an indication of state of protein in food or extrusion blends. Since the proportion of protein in Banjarnegara and Bantul black rice is high, the increase of WSI might be due to partial protein denaturation at higher temperature (Oikonomou and Krokida, 2011). Ito et al. (2015) stated that desirable maximum WSI can be achieved with minimum moisture content (20\%) and high screw speed (200 rpm). The desired high WSI could not be achieved since the screw speed applied in this study was low (80 rpm). Meanwhile, though WSI value of Bantul black rice was decreased after extrusion, the variation of temperature and moisture content did not affect the WSI value significantly $(P>0.05)$.

There was a significant effect $(P<0.001)$ of combined interaction between moisture content, rice varieties, and barrel temperature. As the consequence of the influence from combined interaction between moisture content, rice varieties, and barrel temperature, there also might be optimum WSI value achieved from one condition applied from the three variables. Therefore, due to no-die extrusion cooking, the optimum WSI value $(3.73 \%)$ can be obtained by extruding Bantul black rice with barrel temperature $140^{\circ} \mathrm{C}$ and $15 \%(\mathrm{wb})$ of moisture content as the extrusion cooking condition. Since high value of WSI is desirable in extrusion cooked products such as breakfast cereals and porridge (Oikonomou and Krokida, 2011), extended extrusion cooking studies of black rice are necessary to improve the physical properties of the products.

\section{CONCLUSION}

The heat of no-die extrusion cooking decreased the total phenolic content of waxy Banjarnegara black rice flour but not affected low amylose Bantul black rice flour. No-die extrusion decreased the total anthocyanin content of both Banjarnegara and Bantul black rice flours and higher feed moisture content gave less retention of the total anthocyanin content. DPPH antioxidant activity decreased due to no-die extrusion cooking, but increased when high feed moisture content $(25 \%)$ applied for both Bantul and Banjarnegara black rice flours. The heat of nodie extrusion cooking decreased the FRAP antioxidant activity of Banjarnegara black rice flour but not affected Bantul black rice flour. Increasing heat of no-die extrusion cooking increased the water ab- sorptivity index of Bantul black rice flour, but decreased the water absorptivity index of Bantul black rice flour. In Banjarnegara black rice flour, increasing temperature of no-die extrusion cooking increased water solubility index but increasing feed moisture content decreased its water solubility index. Meanwhile, temperature and feed moisture content of nodie extrusion cooking did not affect the water solubility index of Bantul black rice flour. For future development, it is recommended to utilize Banjarnegara black rice as its antioxidant is higher than Bantul black rice. The processing condition may apply a nodie extrusion cooking at $110^{\circ} \mathrm{C}$ of barrel temperature and more than $25 \%$ of moisture content to achieve fully gelatinised flour with high antioxidant activity.

\section{ACKNOWLEDGEMENT}

This study was supported financially by Indonesian Education Endowment Fund (LPDP, Lembaga Pengelola Dana Pendidikan).

\section{REFERENCES}

Altan A, McCarthy KL, Maskan M. 2009. Effect of extrusion process on antioxidant activity, total phenolics and $\beta$-glucan content of extrudates developed from barley-fruit and vegetable byproducts. Int J Food Sci Technol 44: 12631271. DOI: 10.1111/j.1365-2621.2009.01956.x.

[AOAC] Association of Official Analytical Chemists. 2012. Official methods of analysis. $15^{\text {th }}$ ed. AOAC International, Washington DC, USA.

Birla DS, Malik K, Sainger M, Chaudhary D, Jaiwal R, Jaiwal PK. 2017. Progress and challenges in improving the nutritional quality of rice (Oryza sativa L.). Crit Rev Food Sci Nutr 57: 24552481. DOI: 10.1080/10408398.2015.1084992.

Bobo-García G, Davidov-Pardo G, Arroqui C, Vírseda P, Marín-Arroyo MR, Navarro M. 2014. Intra-laboratory validation of microplate methods for total phenolic content and antioxidant activity on polyphenolic extracts, and comparison with conventional spectrophotometric methods. J Sci Food Agr 95: 204-209. DOI: 10.10 02/jsfa. 6706.

Brennan C, Brennan M, Derbyshire E, Tiwari BK. 2011. Effects of extrusion on the polyphenols, vitamins, and antioxidant activity of foods. Trends Food Sci Tech 22: 570-575. DOI: 10.10 16/j.tifs.2011.05.007.

Budiman, Arisoesilaningsih E, Wibowo RBE. 2012. Growth adaptation of two Indonesian black rice origin NTT cultivating in organic paddy field, 
Malang-East Java. J Trop Life Sci 2: 77-80. DOI: $10.11594 /$ jtls.02.03.04.

Goufo P, Trindade H. 2014. Rice antioxidants: phenolic acids, flavonoids, anthocyanins, proanthocyanidins, tocopherols, tocotrienols, $\gamma$-oryzanol, and phytic acid. Food Sci Nutr 2: 75-104. DOI: 10.1002/fsn3.86.

Handayani AP, Ramakrishnan Y, Karim R, Muhammad K. 2014. Antioxidant Properties, degradation kinetics and storage stability of drinks prepared from the cooking water of pigmented rice. Adv J Food Sci Technol 6: 668679. DOI: 10.19026/ajfst.6.92.

Hartati S. 2013. Pengaruh pengolahan terhadap kandungan poliphenol dan antosianin beras wulung yang berpotensi sebagai makanan diet penderita diabetes mellitus. J Pangan Gizi 4: 57-67.

Hiemori M, Koh E, Mitchell AE. 2009. Influence of cooking on anthocyanins in black rice (Oryza sativa L. japonica var. SBR). J Agr Food Chem 57: 1908-1914. DOI: 10.1021/jf803153z.

Hirth M, Leiter A, Beck SM, Schuchmann HP. 2014. Effect of extrusion cooking process parameters on the retention of bilberry anthocyanins in starch based food. J Food Eng 125: 139-146. DOI: 10.1016/j.jfoodeng.2013.10.034.

Hui $\mathrm{C}$, Bin $\mathrm{Y}$, Xiaoping $\mathrm{Y}$, Long $\mathrm{Y}$, Chunye $\mathrm{C}$, Mantian M, Ling W. 2010. Anticancer activities of an anthocyanin-rich extract from black rice against breast cancer cells in vitro and in vivo. Nutr Cancer 62: 1128-1136. DOI: 10.1080/0163 5581.2010 .494821$.

Ito T, Nakajima M, Isobe S. 2015. Effect of extrusion-cooking variables on the properties of cornstarch with soybean oil. Food Sci Technol Res 21: 359-364. DOI: 10.3136/fstr.21.359.

Kristamtini, Taryono, Basunanda P, Murti RH. 2014. Keragaman genetik dan korelasi parameter warna beras dan kandungan antosianin total sebelas kultivar padi beras hitam lokal. IImu Pertanian 17: 90-103.

Lee SG, Vance TM, Nam TG, Kim DO, Koo SI, Chun OK. 2016. Evaluation of pH differential and HPLC methods expressed as cyanidin-3glucoside equivalent for measuring the total anthocyanin content of berries. J Food Meas Charact 10: 562-568. DOI: $10.1007 / \mathrm{s} 11694-016-93$ 37-9.
Mesquita CDB, Leonel M, Mischan MM. 2013. Effects of processing on physical properties of extruded snacks with blends of sour cassava starch and flaxseed flour. Food Sci Tech 33: 404-410. DOI: 10.1590/S0101-2061201300500 0073.

Min S, Ryu S, Kim D. 2010. Anti-inflammatory effects of black rice, cyanidin-3-O- $\beta$-D-glycoside, and its metabolites, cyanidin and protocatechuic acid. Int Immunopharmacol 10: 959966. DOI: 10.1016/j.intimp.2010.05.009.

Oikonom ou NA, Krokida MK. 2011. Literature data compilation of WAI and WSI of extrudate food products. Int J Food Prop 14: 199-240. DOI: 10.1080/10942910903160422.

Patras A, Brunton NP, O'Donnel C, Tiwari BK. 2010. Effect of thermal processing on anthocyanin stability in foods; mechanisms and kinetics of degradation. Trends Food Sci Tech 21: 3-11. DOI: 10.1016/j.tifs.2009.07.004.

Pratiwi R, Purwestri YA. 2017. Black rice as a functional food in Indonesia. Funct Foods Health Dis 7: 182-194.

Reddy CK, Kimi L, Haripriya S. 2016. Variety difference in molecular structure, functional properties, phytochemical content and antioxidant capacity of pigmented rice. J Food Meas Charact 10: 605-613. DOI: 10.1007/s11694-106-93 44-x.

Sarawong C, Schoenlechner R, Sekiguchi K, Berghofer E, Ng PKW. 2014. Effect of extrusion cooking on the physicochemical properties, resistant starch, phenolic content and antioxidant capacities of green banana flour. Food Chem 143: 33-39. DOI: 10.1016/j.foodchem.2013.07. 081.

Seth D, Badwaik LS, Ganapathy V. 2015. Effect of feed composition, moisture content and extrusion temperature on extrudate characteristics of yam-corn-rice based snack food. J Foof Sci Tech 52: 1830-1838. DOI: 10.1007/s13197-01 3-1181-x.

Sharma P, Gujral HS, Singh B. 2012. Antioxidant activity of barley as affected by extrusion cooking. Food Chem 131: 1406-1413. DOI: 10.1016/j. foodchem.2011.10.009.

Sobukola OP, Babajide JM, Ogunsade O. 2013. Effect of brewers spent grain addition and extrusion parameters on some properties of extruded yam starch-based pasta. J Food Process Pres 37: 734-743. DOI: 10.1111/j.17454549.2012.00711.x. 
Sompong R, Siebenhandl-Ehn S, Berghofer E, Schoenlechner R. 2011. Extrusion cooking properties of white and coloured rice varieties with different amylose content. Starch-Stärke 63: 5563. DOI: 10.1002/star.201000086.

Stojceska V, Ainsworth $P$, Plunkett A, İbanoğlu Ş. 2009. The effect of extrusion cooking using different water feed rates on the quality of ready to-eat snacks made from food by-products. Food Chem 114: 226-232. DOI: 10.1016/j.food chem.2008.09.043.

Tang Y, Cai W, Xu B. 2015. From rice bag to table: Fate of phenolic chemical compositions and antioxidant activities in waxy and non-waxy black rice during home cooking. Food Chem 191: 81-90. DOI: 10.1016/j.foodchem.2015.02. 001.

Ti H, Zhang R, Zhang M, Wei Z, Chi J, Deng Y, Zhang Y. 2015. Effect of extrusion on phytochemical profiles in milled fractions of black rice. Food Chem 178: 186-194. DOI: 10.1016/j.food chem.2015.01.087.

Zhang M, Zhang RF, Zhang FX, Liu RH. 2010. Phenolic profiles and antioxidant activity of black rice bran of different commercially available varieties. J Agr Food Chem 58: 7580-7587. DOI: $10.1021 / \mathrm{jf1} 1007665$. 